\title{
Effect of Physical Training on the Levels of Sex Hormones and the Expression of Their Receptors in Rats With Induced Mammary Cancer in Secondary Prevention Model - Preliminary Study
}

\author{
KATARZYNA SIEWIERSKA ${ }^{1}$, IWONA MALICKA ${ }^{1}$, CHRISTOPHER KOBIERZYCKI $^{2}$, \\ JEDRZEJ GRZEGRZOLKA ${ }^{2}$, ALEKSANDRA PIOTROWSKA $^{2}$, URSZULA PASLAWSKA $^{3}$, MAREK CEGIELSKI $^{2}$, \\ MARZENNA PODHORSKA-OKOLOW ${ }^{4}$, PIOTR DZIEGIEL ${ }^{1,2}$ and MAREK WOZNIEWSKI ${ }^{1}$ \\ ${ }^{1}$ Department of Physiotherapy, University School of Physical Education, Wroclaw, Poland; \\ ${ }^{2}$ Division of Histology and Embryology, Department of Human Morphology and Embryology, \\ Wroclaw Medical University, Wroclaw, Poland; \\ ${ }^{3}$ Department of Internal Medicine and Clinic of Diseases of Horses, Dogs, and Cats, \\ University of Environmental and Life Sciences, Wroclaw, Poland; \\ ${ }^{4}$ Division of Ultrastructure Research, Department of Human Morphology and Embryology, \\ Wroclaw Medical University, Wroclaw, Poland
}

\begin{abstract}
Background/Aim: Breast cancer is the most common malignant tumor among women worldwide. In previous work, we presented results of physical activity in primary prevention in a model of induced mammary gland cancer. In the present study, we assessed the influence of physical activity on sex hormone levels (estradiol and progesterone) and the expression of their receptors $(E R, P R)$, as well as the level of apoptosis of tumor cells in secondary prevention. Materials and Methods: Fifty 1-month-old female Sprague-Dawley rats received intraperitoneal injection of 180 $\mathrm{mg} / \mathrm{kg}$ body weight of $\mathrm{N}$-methyl-N-nitrosourea (MNU) for tumor induction. Three months after the administration of $M N U$, rats were divided into four groups: low-intensity, moderate-intensity, and high-intensity physical training groups (combined as PT) and a sedentary control (SC) group. Physical training was conducted 5 days per week with a threeposition treadmill according to a precisely described protocol.
\end{abstract}

This article is freely accessible online.

Correspondence to: Christopher Kobierzycki, MD, Ph.D., Division of Histology and Embryology, Department of Human Morphology and Embryology, Wroclaw Medical University, Chalubinskiego 6a, 50-367 Wroclaw, Poland. E-mail: christopher.kobierzycki@umed. wroc.pl

Key Words: Estrogen receptor, progesterone receptor, estradiol, progesterone, breast cancer, physical activity, $\mathrm{N}$-methyl- $\mathrm{N}$ nitrosourea, rat experimental model.
The entire training was completed by 32 rats from which tissue and blood were collected for further analysis. Immunohistochemistry for ER and PR expression, terminal deoxynucleotidyl transferase dUTP nick-end labeling method for detection of apoptosis, and enzyme-linked fluorescent assay for detection of plasma hormone levels (estradiol and progesterone) were performed. Statistical analysis used $p<0.05$ as the significance level. Results: Significantly stronger expression of ER and $P R$ was found in the $S C$ in comparison to the PT group ( $p=0.035$ and $p=0.036$, respectively). No statistically significant differences were found in estradiol or progesterone concentrations between $S C$ and PT groups. Apoptosis was non-significantly increased in the PT group in comparison with the SC group. Stronger apoptosis in the PT group correlated positively with the level of training intensity $(r=0.35, p=0.05)$. Conclusion: Physical training may reduce ER and PR expression in breast cancer cells, and reduce cell sensitivity to pro-proliferative and antiapoptotic effects of estrogens, ultimately leading to apoptosis.

Breast cancer is the most common malignant tumor among women worldwide $(30 \%)$, being the second leading cause of cancer-related death in the United States and in Europe (14\%) (1). Nearly $20 \%$ of women worldwide are diagnosed at 30-49 years of age and over $40 \%$ of women aged 65 years or over (2).

Estrogens play an important role in the pathogenesis of breast cancer. Estradiol stimulates cell proliferation and differentiation by estrogen receptor (ER). Many reports indicate the relationship between exposure to estrogens and 
breast cancer. The risk of breast cancer is associated with increased exposure to endogenous and exogenous sex hormones in cases of an early age of menarche, late age of menopause, late first pregnancy (after 30 years of age) and hormone replacement therapy $(3,4)$. Moreover, risk increases with age and is the highest in the postmenopausal period, when the main source of estrogens is peripheral adipose tissue (3-5). Hence, hormonal imbalance and obesity are important risk factors for breast cancer (5-7).

Many reports suggest that physical activity is associated with a reduction in the risk of breast cancer and its recurrence. Physical activity can reduce the body weight, the amount of fat tissue and endogenous conversion to estrogens (8). Regular physical training leads to a decrease in estradiol and progesterone by reducing the ovarian secretory function, which can have a protective role against breast cancer (9). In this field contrary observations may be found. McTiernan et al. showed a decrease in estrogen level and an increase in serum level of sex hormone binding globulin as a result of physical exercise (10), while Atkinson et al. did not confirm the expected changes in estrogen metabolites as a consequence of physical activity (11). Further studies are strongly needed and an experimental rat model with tumors induced by $N$-methyl- $N$-nitrosourea (MNU) due to the similarity of the structure and function with a human mammary gland seems to be reliable and relevant (12).

The aim of our project entitled "Impact of Physical Training on the Carcinogenesis and Progression of Rat Mammary Glands" was the assessment of the impact of physical training on the course of cancer, depending on the intensity of exercise training and the examined prevention model. The results related to primary prevention were presented by Malicka et al. (13), whereas initial results related to secondary prevention were presented by Siewierska et al. (14). In the present article, we report the assessment of the influence of physical activity on sex hormone levels (estradiol and progesterone) and the expression of their receptors (ER, PR), as well as the level of apoptosis of tumor cells in the model of secondary prevention.

\section{Materials and Methods}

Animals. For the whole project, fifty 1-month-old female SpragueDawley rats obtained from the Medical University of Silesia (Katowice, Poland) were used. All the procedures, e.g. housing, feeding and tumor induction [intraperitoneal injection of $180 \mathrm{mg} / \mathrm{kg}$ body weight of MNU (Sigma-Aldrich, Germany)] were performed in accordance with the protocol described by Malicka et al. (13). The project met the European Union standards and was approved by the Institute of Immunology and Experimental Therapy of the Polish Academy of Sciences (consent number 37/2010).

Physical training. Three months after the administration of MNU, rats were divided into four groups, i.e.: low-intensity $(\mathrm{n}=12)$, moderateintensity $(\mathrm{n}=12)$, high-intensity $(\mathrm{n}=12)$ physical training groups (PT); and a sedentary control group (SC; $\mathrm{n}=14)$. Physical training was conducted 5 days per week with a three-position treadmill (Exer 3/6;
Table I. Protocol of moderate-intensity training.

\begin{tabular}{lcc}
\hline Training phase (week) & Speed $(\mathrm{km} / \mathrm{h})$ & Duration $(\mathrm{min})$ \\
\hline 1 & 0.60 & 10 \\
2 & 0.96 & 20 \\
3 & 1.20 & 30 \\
4 & 1.44 & 40 \\
5 & 1.68 & 50 \\
6 & 1.68 & 55 \\
7 & 1.68 & 60 \\
8 & 1.68 & 65 \\
$9-12$ & 1.68 & 30 \\
\hline
\end{tabular}

Columbus Instruments, Columbus, OH, USA) according to the previously described protocol (9). The speed and the duration of training on the treadmill were gradually increased depending on the group's defined level of intensity (Table I). The parameters of the low-intensity group were $20 \%$ lower and those of the high-intensity group were $20 \%$ higher than those of the moderate-intensity group. The entire training was completed by 32 rats.

Tissue collection. Six months following MNU administration, the animals were sacrificed $(13,14)$. All tumors in the animals that were detected on palpation were collected and measured. The obtained tissues were fixed in $4 \%$ buffered formalin and then embedded in paraffin blocks. Subsequently, for future immunohistochemistry assays, tissue microarrays (TMAs) were prepared using a 2-mmgauge needle and Manual Tissue Arrayer I (Beecher Instruments Inc., Sun Prairie, WI, USA). Moreover, for biochemical assays, the blood was collected, centrifuged $\left(500 \times \mathrm{g}\right.$ for $15 \mathrm{~min}$ at $\left.4^{\circ} \mathrm{C}\right)$ and the obtained plasma was frozen.

Immunohistochemistry. All reactions were performed on 4- $\mu$ m-thick TMA sections in an automated Autostainer Link48 staining platform. Deparaffinization, rehydratation, and antigen retrieval were performed by boiling the sections in Target Retrieval Solution buffer using a Pre-Treatment Link Platform. The sections were incubated with the EnVision FLEX Peroxidase-Blocking Reagent to block the endogenous peroxidase activity. Subsequently, the sections were incubated with the polyclonal rabbit anti-rat primary antibodies directed against ER $\alpha$ (1:100; Novus Biologicals, Abingdon, UK) and PR (1:100; Novus Biologicals). The sections were then incubated (20 $\mathrm{min}$ at room temperature; RT) with EnVision FLEX Horseradish Peroxidase-conjugated secondary antibodies. The substrate for peroxidase, diaminobenzidine, was then applied and the sections were incubated at RT for $10 \mathrm{~min}$. Finally, the sections were rinsed and counterstained with Mayer's hematoxylin and mounted using SUB-X Mounting Medium. All the reagents, except primary antibodies, and equipment used for the reactions were provided by Dako (Glostrup, Denmark).

Terminal deoxynucleotidyl transferase dUTP nick-end labeling (TUNEL) method. The apoptosis assay was conducted using ApopTag in situ Apoptosis Detection Kit (Millipore, Billerica, MA, USA). TMA sections were dewaxed in xylene, rehydrated in ethanol and rinsed with distilled water and phosphate-buffered saline. The sections were digested using Proteinase K (Dako) for 5 min at RT. The activity of endogenous peroxidase was blocked by 5-min 

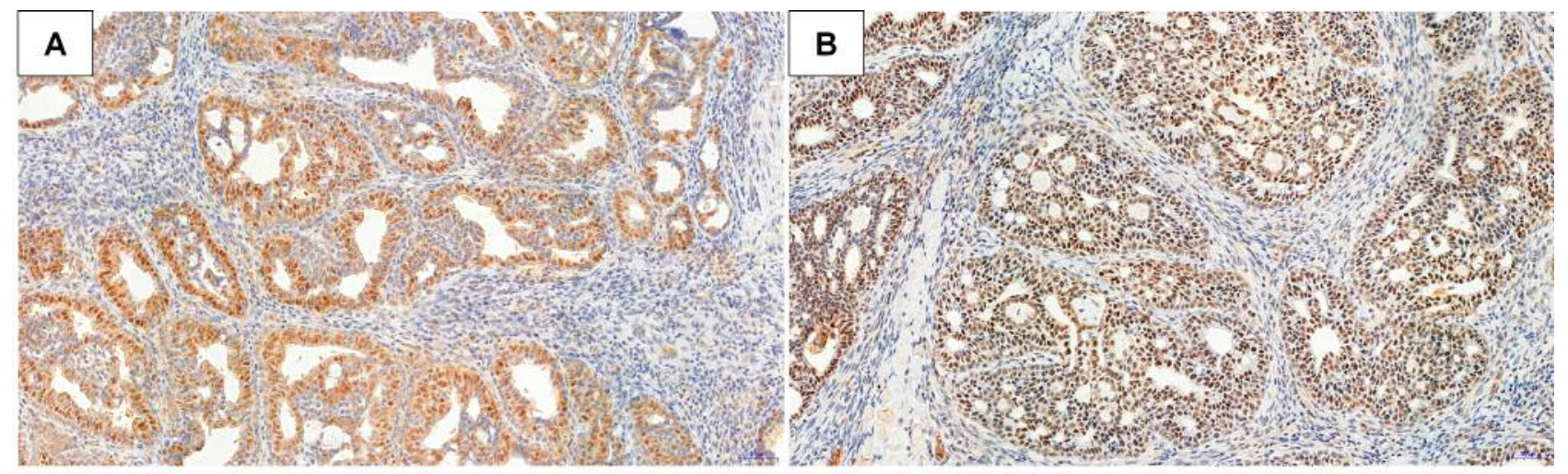

C

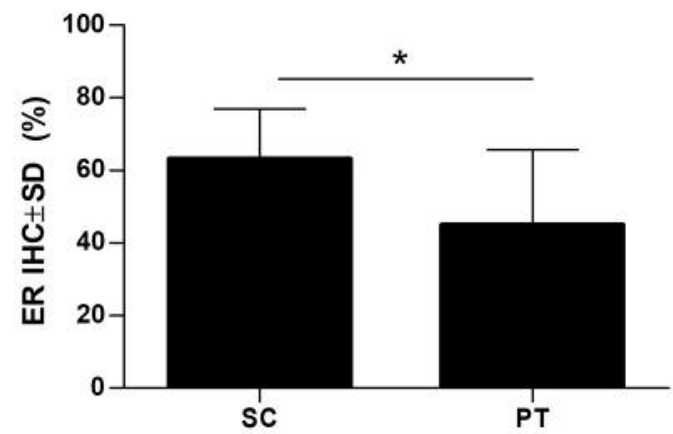

$\mathbf{E}$

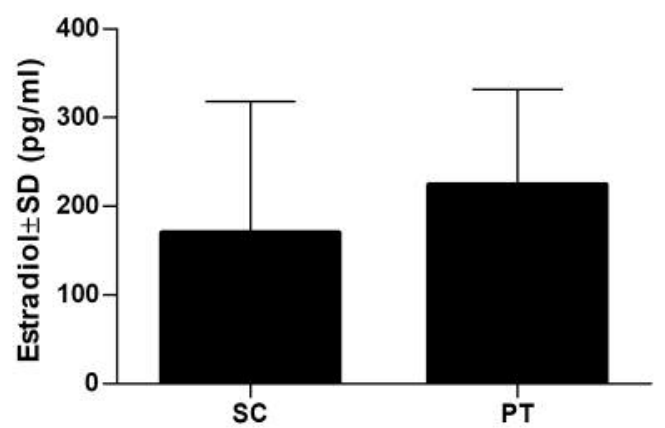

D

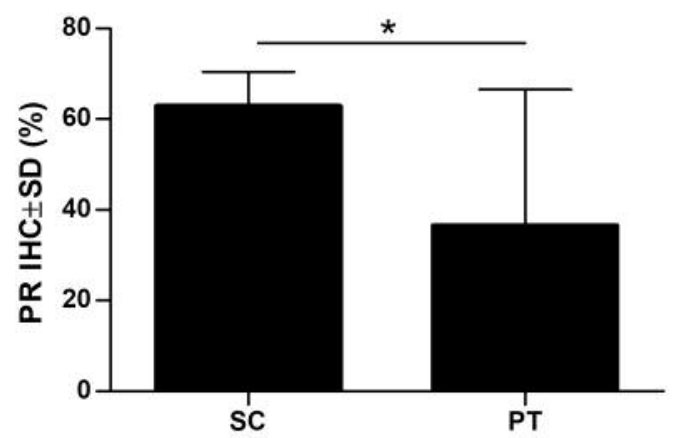

$\mathbf{F}$

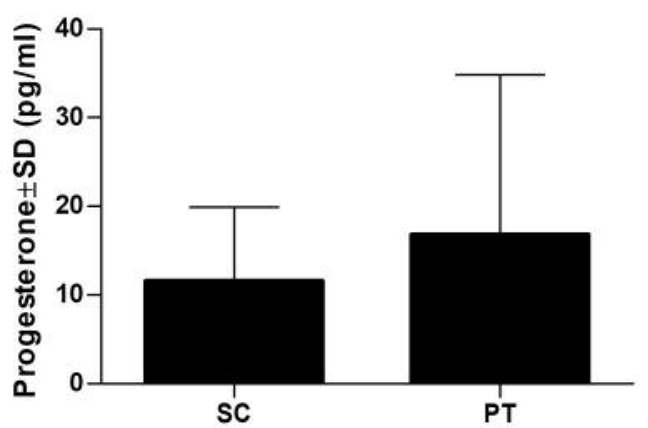

Figure 1. Immunohistochemical (IHC) scores for nuclear expression of estrogen receptor (ER; A) and progesterone receptor (PR, B) in tumor cells of induced mammary gland cancer. Comparison of ER $(C)$ and $P R(D)$ expression and plasma level of estradiol $(E)$ and progesterone $(F)$ between $S C$ and PT groups. The values are expressed as the mean $\pm S D$. *Significantly different at $p<0.05$.

incubation in $3 \% \mathrm{H}_{2} \mathrm{O}_{2}$ in phosphate-buffered saline. The sections were incubated, first with Equilibration Buffer for $10 \mathrm{~min}$ at RT and then with TdT Enzyme and Reaction Buffer at $37^{\circ} \mathrm{C}$ for $1 \mathrm{~h}$. The reaction was terminated by incubation with Stop Buffer for $10 \mathrm{~min}$ at RT. Subsequently, the sections were incubated with antidigoxigenin peroxidase-conjugated secondary antibodies and diaminobenzidine was applied for $10 \mathrm{~min}$ at RT. Finally, the sections were counterstained with Mayer's hematoxylin and mounted in SUB-X Mounting Medium (Dako).
Evaluation of the reactions. All TMA sections were evaluated under a BX-41 light microscope equipped with Cell ${ }^{\mathrm{D}}$ software for computer-assisted image analysis (Olympus, Tokyo, Japan). For the evaluation of ER, PR and TUNEL reaction in the TMA sections, three fields with the highest number of tumor cells yielding a color reaction were selected (hot spots). The percentage of positively stained cells was evaluated by scoring labeled cells in relation to all cancer cells distinguished under $\times 400$ magnification. The final score was the average of three hot-spot values for each case. 

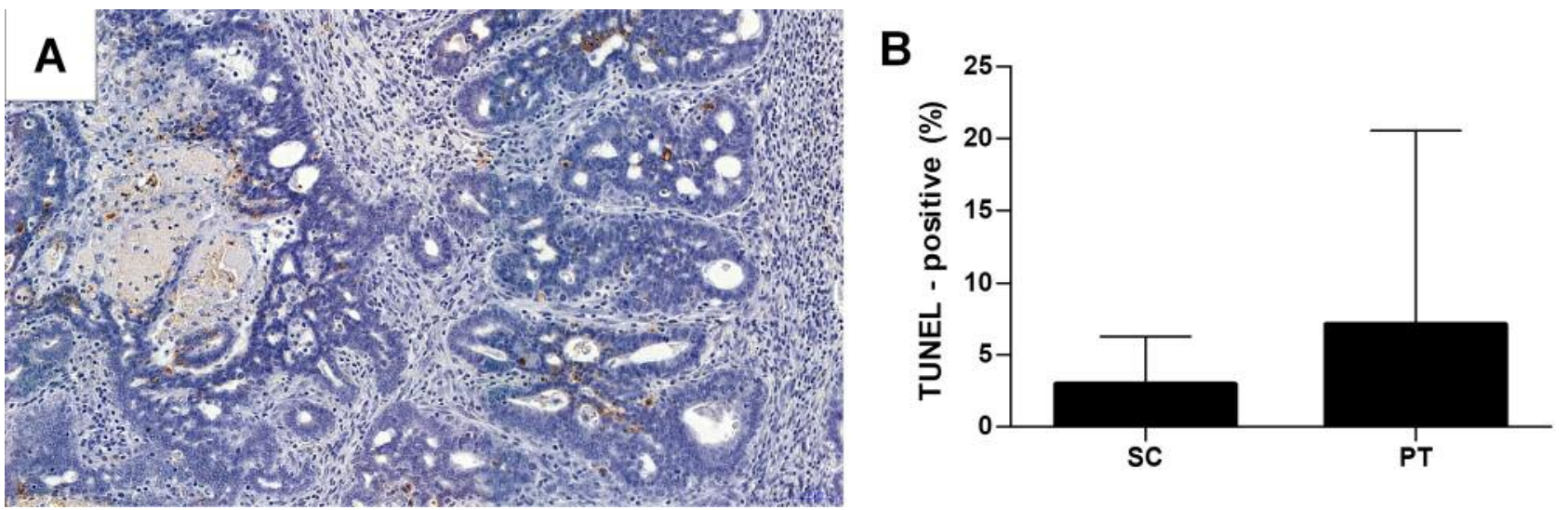

Figure 2. A: Visualization of cells undergoing apoptosis by terminal deoxynucleotidyl transferase dUTP nick-end labeling (TUNEL) method. B: Comparison of apoptosis level between sedentary control (SC) and physical training (PT) groups. The values are expressed as the mean $\pm S D$.

Table II. Clinicomorphological parameters of the study animals.

\begin{tabular}{|c|c|c|c|c|c|c|}
\hline & & $\mathrm{SC}$ group $(\mathrm{n}=8)$ & LIT group $(n=9)$ & MIT group (n=9) & HIT group $(n=6)$ & $p$-Value \\
\hline Number of rats with tumors & Total & $7(87.5 \%)$ & $6(66.6 \%)$ & $9(100 \%)$ & $4(66.6 \%)$ & $0.92 *$ \\
\hline Number of tumors & Total & 24 & 10 & 12 & 21 & $0.16^{*}$ \\
\hline Number of tumors per rat & Total & 3.00 & 1.22 & 1.44 & 3.5 & \\
\hline \multirow[t]{6}{*}{ Histological type (n) } & Cribriform & $12(50 \%)$ & $3(30 \%)$ & $6(50 \%)$ & $15(71.43 \%)$ & $0.13 *$ \\
\hline & Papillary & $1(4.17 \%)$ & $4(40 \%)$ & $3(25 \%)$ & $1(4.76 \%)$ & \\
\hline & Tubular & $8(33.33 \%)$ & $2(20 \%)$ & $2(16.67 \%)$ & $4(19.05 \%)$ & \\
\hline & Solid & $3(12.5 \%)$ & 0 & 0 & $1(4.76 \%)$ & \\
\hline & Carcinosarcoma & 0 & 0 & $1(8.83 \%)$ & 0 & \\
\hline & Planoepithelial & 0 & $1(10 \%)$ & 0 & 0 & \\
\hline $\begin{array}{l}\text { Body weight at MNU } \\
\text { administration }(\mathrm{g})\end{array}$ & Mean \pm SD & $133.87 \pm 11.67$ & $118.88 \pm 32.57$ & $118.88 \pm 39.19$ & $97.50 \pm 5.68$ & $0.15^{\#}$ \\
\hline MNU dose $(\mathrm{ml} / \mathrm{kg})$ & Mean \pm SD & $2.41 \pm 0.19$ & $2.15 \pm 0.49$ & $2.10 \pm 0.55$ & $1.76 \pm 0.10$ & $0.12^{\#}$ \\
\hline Body weight at euthanasia ( $g$ ) & Mean \pm SD & $311.00 \pm 35.58$ & $307.77 \pm 30.31$ & $292.77 \pm 25.49$ & $319.83 \pm 52.36$ & $0.6^{\#}$ \\
\hline Volume of tumors $\left(\mathrm{mm}^{3}\right)$ & Mean \pm SD & $2853.81 \pm 4698.39$ & $907.83 \pm 1287.19$ & $1664.16 \pm 2024.16$ & $3107.67 \pm 5503.22$ & $0.8^{\#}$ \\
\hline Total tumor per rat $\left(\mathrm{mm}^{3}\right)$ & & 356.70 & 100.87 & 184.90 & 517.94 & \\
\hline Volume of tumors $\left(\mathrm{mm}^{3}\right)$ & Mean \pm SD & $849.37 \pm 1138.61$ & $670.69 \pm 1130.41$ & $1193.27 \pm 1581.44$ & $453.57 \pm 519.68$ & $0.75^{\#}$ \\
\hline Volume of tumors per rat $\left(\mathrm{mm}^{3}\right)$ & & 106.17 & 74.52 & 132.58 & 75.59 & \\
\hline
\end{tabular}

LIT: Low-intensity training, MIT: moderate-intensity training HIT: high-intensity training SC: sedentary control, SD: Standard deviation. ${ }^{*}$ Chisquare test; \#Kruskal-Wallis test.

Determination of plasma hormone levels. $17 \beta$-Estradiol and progesterone in serum were determined by enzyme-linked fluorescent assay (BioMerieux, Marcy-L'etoile, France), according to the manufacturer's recommendations. All steps were performed automatically by a VIDAS immunoanalyzer (BioMerieux), including the automated calculation of the results in relation to the programmed calibration curve.

Statistical analysis. Shapiro-Wilk, Levene, Spearman, MannWhitney and Kruskal-Wallis tests were used in our study. Statistical analysis was performed using Statistica 10.0 (Statsoft, Cracow, Poland) and Prism 7.0 (GraphPad, La Jolla, CA, USA). The results were considered statistically significant at $p<0.05$.

\section{Results}

Fifty rats started physical training, of which 32 finished it. Statistical analysis was performed only for those animals with induced tumors (seven rats in SC; 19 in PT). Due to the fact that the groups were small in size, rats were assessed as two groups, namely the PT group (regardless of training intensity) and the SC group. The expression of ER and PR was observed in nuclei of cancer cells (Figure 1A and B). Significantly stronger expression of ER ( $p=0.035$, Figure $1 C)$ and PR $(p=0.036$, Figure 1D) were found in the SC in comparison to 
the PT group. No statistically significant differences were found in estradiol or progesterone concentrations between the SC and PT groups (Figure 1E and F). Apoptosis was increased in the PT group, however, in comparison with the SC group, the difference was not statistically significant (Figure 2). Stronger apoptosis in the PT group positively correlated with the level of training intensity $(\mathrm{r}=0.35, p=0.05)$. There were no statistically significant differences in terms of described clinical features between individual groups at the beginning and at the end of the experiment (Table II).

\section{Discussion}

Many scientific reports indicate a protective effect of physical activity on breast cancer $(8,9,13,15-17)$, including in patients after comprehensive breast cancer treatment $(8,9,18-24)$. From the results of our study, we found two mechanisms which confirm these observations, namely desensitization of cells due to reduced expression of ER and PR, as well as increased apoptosis which positively correlated with the level of training intensity.

The reduction in ovarian secretory activity that results in a decrease in sex hormone levels in the blood is one of the mechanisms that reduce the risk of breast cancer or its recurrence as a result of physical activity. Others suggest that physical training increases levels of sex hormone-binding globulin. In experimental studies Brown et al. showed that mammary cancer was statistically significantly less prevalent in physically active rats compared to less active controls (25). Brown et al. also reported that women exposed to high estradiol concentrations had an increased risk of breast cancer. After 12 months of exercise, levels of hormones circulating in the blood decreased. Further decrease was observed after reduction in body weight $(25,26)$.

According to another hypothesis, physical training does not significantly reduce levels of sex hormones but significantly reduces the expression of their receptors $(9,17$, 27). A reduction in receptor expression results in the lack of cell stimulation by sex hormones, followed by cell apoptosis (17). We found statistically insignificant differences between the estradiol levels in PT $v s$. SC groups, in accordance with other authors $(9,15,28)$.

Estradiol affects only cells showing ER expression, while the absence of ER prevents hormonal influence $(27,29-31)$. In addition, statistically significantly lower ER and PR IHC scores were found in the PT groups in our study. Wang et al. also reported reduced expression of ER as a result of physical training (32). However, Faustino-Roch et al. obtained different results (27).

Many authors point to the key role of estradiol in inducing apoptosis in breast cancer cells (33-35). Our study also revealed increased apoptosis in the training groups (although statistically insignificant) which was associated with reduced tumor volume $(17,36)$. Figueira et al. observed a positive effect of long-term moderate physical activity on the development of breast tumors and the balance between cell proliferation and apoptosis. Similarly, Westerlind et al. found statistically significantly higher apoptosis in physically trained rats compared to non-exercised animals (17). Coelingh et al. reported an anti-apoptotic effect of estrogens (37).

Based on the preliminary results, we conclude that physical training may reduce the expression of ER and PR by breast cancer cells. Moreover, it may reduce cell sensitivity to proproliferative and anti-apoptotic effects of estrogens, finally leading to their apoptosis. The findings obtained from this model of secondary prevention need further testing to overcome the main study limitation of a small number of cases and to strengthen this research hypothesis.

\section{Conflicts of Interest}

The Authors declare no conflicts of interest regarding this study.

\section{Authors' Contributions}

KS, IM, MPO, PD and MW conceived the study design. KS, IM, AP, UP and MC conducted the experiment. JG performed statistical analysis. KS, CK and JG analyzed the results. KS and IM performed literature reviews and drafted the article. CK revised the article. All Authors read and approved the final article.

\section{Acknowledgements}

The Authors thank Bozena Przygodzka, Agnieszka Baranska and Elzbieta Polejko for their technical assistance. This work was funded by the grant of the Polish Ministry of Science NN404088240 "Impact of Physical Training on the Carcinogenesis and Progression of Rat Mammary Glands".

\section{References}

1 Siegel RL, Miller KD and Jemal A: Cancer statistics, 2018. Ca Cancer J Clin 68: 7-30, 2018. PMID: 29313949. DOI: $10.3322 /$ caac 21442

2 Miller KD, Siegel RL, Lin CC, Marietto AB, Kramer JL, Rowland JH, Stein KD, Alteri R and Jemal A: Cancer treatment and survivorship statistics 2016. Ca Cancer J Clin 66: 271-289, 2016. PMID: 27253694. DOI: 10.3322/caac.21349

3 Picon-Ruiz M, Morata-Tarifa C, Valle-Goffin JJ, Friedman ER and Slingerland JM: Obesity and adverse breast cancer risk and outcome: Mechanistic insights and strategies for intervention. Ca Cancer J Clin 67: 378-397, 2017. PMID: 28763097. DOI: 10.3322/caac. 21405

4 Nimptsch K and Pischon T: Obesity biomarkers, metabolism and risk of cancer: An epidemiological perspective. Recent Results Cancer Res 208: 199-217, 2016. PMID: 27909909. DOI: 10.1007/978-3-319-42542-9_11

5 Berriel Diaz M, Herzig $S$ and Schafmeier T: Biological mechanisms for the effect of obesity on cancer risk: Experimental evidence. Recent Results Cancer Res 208: 219-242, 2016. PMID: 27909910. DOI: 10.1007/978-3-319-42542-9_12 
6 Fortner RT, Katzke V, Kühn T and Kaaks R: Obesity and breast cancer. Recent Results Cancer Res 208: 43-65, 2016. PMID: 27909901. DOI: 10.1007/978-3-319-42542-9_3

7 Zhang X, Rice M, Tworoger SS, Rosner BA, Eliassen AH, Tamimi RM, Joshi AD, Lindstrom S, Qian J, Colditz GA, Willett WC, Kraft P and Hankinson SE: Addition of a polygenic risk score, mammographic density, and endogenous hormones to existing breast cancer risk prediction models: A nested casecontrol study. PLoS Med 15: e1002644, 2018. PMID: 30180161. DOI: 10.1371/journal.pmed.1002644

8 Adraskela K, Veisaki E, Koutsilieris M and Philippou A: Physical exercise positively influence breast cancer evolution. Clin Breast Cancer 17: 408-417, 2017. PMID: 28606800. DOI: 10.1016/j.clbc.2017.05.003

9 Thompson HJ, Wolfe P, McTiernan A, Jiang W and Zhu Z: Wheel running induced changes in plasma biomarkers and the carcinogenic response in the 1-methyl-1-nitrosourea induced rat model for breast cancer. Cancer Prev Res 3: 1484-1492, 2010. PMID: 20876731. DOI: 10.1158/1940-6207.CAPR-10-0078

10 McTiernan A, Tworger SS, Ulrich CM, Yasui Y, Irwin ML, Rajan KB, Sorensen B, Rudolph RE, Bowen D, Stanczyk FZ, Potter JD and Schwartz RS: Effect of exercise on serum estrogens in postmenopausal women: A 12-month randomized clinical trial. Cancer Res 64: 2923-2928, 2004. PMID: 15087413. DOI: 10.1158/0008-5472.can-03-3393

11 Atkinson C, Lampe JW, Tworoger SS, Ulrich CM, Bowen D, Irwin ML, Schwartz RS, Rajan BK, Yasui Y, Potter JD and McTiernan A: Effects of a moderate intensity exercise intervention on estrogen metabolism in postmenopausal women. Cancer Epidemiol Biomarkers Prev 13: 868-874, 2004. PMID: 15159321.

12 Goutianos G, Tzioura A, Kyparos A, Paschalis V, Margaritelis NV, Veskoukis AS, Zafeiridis A, Dipla K, Nikolaidis MG and Vrabas IS: The rat adequately reflects human responses to exercise in blood biochemical profile: A comparative study. Physiol Rep 3: 1-9, 2015. PMID: 25677548. DOI: 10.14814/phy2.12293

13 Malicka I, Siewierska K, Pula B, Kobierzycki C, Haus D, Paslawska U, Cegielski M, Dziegiel P, Podhorska-Okolow M and Wozniewski M: The effect of physical training on the $N$ methyl- $N$-nitrosourea-induced mammary carcinogenesis of Sprague-Dawley rats. Exp Biol Med 240: 1408-1415, 2015. PMID: 25990440. DOI: 10.1177/1535370215587532

14 Siewierska K, Malicka I, Kobierzycki C, Paslawska U, Cegielski M, Grzegrzolka J, Piotrowska A, Podhorska-Okolow M, Dziegiel P and Wozniewski M: The impact of exercise training on breast cancer. In Vivo 32: 249-254, 2018. PMID: 29475906. DOI: 10.21873/invivo.11231

15 Roon M, May AM, McTiernan A, Scholten RJPM, Peeters PHM, Friedenreich CM and Monninkhof EM: Effect of exercise and/or reduced calorie dietary interventions on breast cancer-related endogenous sex hormones in healthy postmenopausal women. Breast Cancer Res 20: 81, 2018. PMID: 30071893. DOI: 10.1186/s13058-018-1009-8

16 Friedenreich CM, Woolcott CG, McTiernan A, Ballard-Barbash R, Brant RF, Stanczyk FZ, Terry T, Boyd NF, Yaffe MJ, Irwin MI, Jones CA, Yasui Y, Campbell KL, McNeely MI, Karvinen $\mathrm{KH}$ and Wang Q: Alberta physical activity and breast cancer prevention trial: sex hormone changes in a year-long exercise intervention among postmenopausal women. J Clin Oncol 28 : 1458-1466, 2010. PMID: 20159820. DOI: 10.1200/JCO. 2009.24 .9557
17 Westerlind KC, McCarty HL, Gibson KJ and Strange R: Effect of exercise on the rat mammary gland: implications for carcinogenesis. Acta Physiol Scand 175: 147-156, 2002. PMID: 12028135. DOI: 10.1046/j.1365-201X.2002.00980.x

18 Courneya KS, Segal RJ, McKenzie DC, Dong H, Gelmon K, Friedenreich CM, Yasui Y, Reid RD, Crawford JJ and Mackey JR: Effects of exercise during adjuvant chemotherapy on breast cancer outcomes. Med Sci Sports Exerc 46: 1744-1751, 2014. PMID: 24633595. DOI: 10.1249/MSS.0000000000000297

19 Holick CN, Newcomb PA, Trentham-Dietz A, Titus-Ernstoff L, Bersch AJ, Stampfer MJ, Baron JA, Egan KM and Willett WC: Physical activity and survival after diagnosis of invasive breast cancer. Cancer Epidemiol Biomarkers Prev 17: 379-386, 2008. PMID: 18250341. DOI: 10.1158/1055-9965.EPI-07-0771

20 Swisher AK, Abraham J, Bonner D, Gilleland D, Hobbs G, Kurian S, Yanosik MA and Vona-Davis L: Exercise and dietary advice intervention for survivors of triple-negative breast cancer: effects on body fat, physical function, quality of life, and adipokine profile. Support Care Cancer 23: 2995-3003, 2015. PMID: 25724409. DOI: 10.1007/s00520-015-2667-z

21 Agostini D, Natalucci V, Baldelli G, De Santi M, Zeppa SD, Vallorani L, Annibalini G, Lucertini F, Federici A, Izzo R, Stocchi V and Barbieri E: New insights into the role of exercise in inhibiting mTOR signaling in triple-negative breast cancer. Oxid Med Cell Longev 2018, 2018. PMID: 30363988. DOI: 10.1155/2018/5896786

22 Chen X, Lu W, Zheng W, Gu K, Matthews CE, Chen Z, Zheng $\mathrm{Y}$ and Shu XO: Exercise after diagnosis of breast cancer in association with survival. Cancer Prev Res 4: 1409-1418, 2011. PMID: 21795422. DOI: 10.1158/1940-6207.CAPR-10-0355

23 Bradshaw PT, Ibrahim JG, Khankari N, Cleveland RJ, Abrahamson PE, Stevens J, Satia JA, Teitelbaum SL, Neugut AI and Gammon MD: Post-diagnosis physical activity and survival after breast cancer diagnosis: The Long Island Breast Cancer Study. Breast Cancer Res Treat 145: 735-742, 2014. PMID: 24789444. DOI: 10.1007/s10549-014-2966-y

24 Bao PP, Zhao GM, Shu XO, Peng P, Cai H, Lu W and Zheng Y: Modifiable lifestyle factors and triple-negative breast cancer survival: A population-based prospective study. Epidemiology 26: 909-916, 2015. PMID: 26360370. DOI: 10.1097/EDE. 0000000000000373

25 Brown JC, Winters-Stone K, Lee A and Schmitz KH: Cancer, physical activity, and exercise. Compr Physiol 2: 2775-2809, 2012. PMID: 23720265. DOI: 10.1002/cphy.c120005

26 Dierssen-Sotos T, Palazuelos-Calderón C, Jiménez-Moleón JJ, Aragonés N, Jone M. Altzibar JM, Castaño-Vinyals G, MartínSanchez V, Gómez-Acebo I, Guevara M, Tardón A, PérezGómez B, Amiano P, Moreno V, Molina AJ, Alonso-Molero J, Moreno-Iribas C, Kogevinas M, Pollán $\mathrm{M}$ and Llorca J: Reproductive risk factors in breast cancer and genetic hormonal pathways: A gene-environment interaction in the MCC-Spain Project Trynidad Dierssen-Sotos. BMC Cancer 18: 280, 2018. PMID: 29530003. DOI: 10.1186/s12885-018-4182-3

27 Faustino-Rocha AI, Gama A, Oliviera PA, Alvarado A, Neuparth MJ, Ferreira R and Ginja M: Effects of lifelong exercise training on mammary tumorigenesis induced by $\mathrm{MNU}$ in female Sprague-Dawley rats. Clin Exp Med 17: 151-160, 2017. PMID: 27094311. DOI: 10.1007/s10238-016-0419-0

28 Teixeira GR, Favaro WJ, Pinheiro PF, Chuffa LG, Amorim JP, Mendes LO, Fioruci BA, Oba E, Martins OA, Martinez M and 
Martinez FE: Physical exercise on the rat ventral prostate: Steroid hormone receptors, apoptosis and cell proliferation. Scand J Med Sci Sports 22: 86-92, 2012. PMID: 22830442. DOI: $10.1111 / \mathrm{j} .1600-0838.2012 .01501 . \mathrm{x}$

29 Badowska-Kozakiewicz AM and Malicka E: Ocena immunohistochemiczna ekspresji receptorów estrogenowych w nowotworach gruczołu sutkowego suk. Życie weterynaryjne 84 548-549, 2008.

30 May FE: Novel drugs that target the estrogen-related receptor alpha: their therapeutic potential in breast cancer. Cancer Manag Res 6: 223-252, 2017. PMID: 24904222. DOI: 10.2147/CMAR. S35024

31 Friedenreich CM, Neilson HK, Farris MS and Courneya KS: Physical activity and cancer outcomes: a precision medicine approach. Clin Cancer Res 22: 4766-4775, 2016. PMID: 27407093. DOI: 10.1158/1078-0432.CCR-16-0067

32 Wang M, Yu B, Westerlind K, Strange R, Khan G, Patil D, Boeneman K and Hilakivi-Clarke L: Prepubertal physical activity up-regulates estrogen receptor $\beta, B R C A 1$ and $p 53$ mRNA expression in the rat mammary gland. Breast Cancer Res Treat 115: 213-220, 2009. PMID: 18516675. DOI: 10.1007/ s10549-008-0062-x

33 Song RX, Mor G, Naftolin F, McPherson RA, Song J, Zhang Z, Yue W, Wang $J$ and Santen RJ: Effect of long-term estrogen deprivation on apoptotic responses of breast cancer cells to 17beta-estradiol. J Natl Cancer Inst 93: 1714-1723, 2001. PMID: 11717332. DOI: $10.1093 /$ jnci/93.22.1714
34 Lewis JS, Meeke K, Osipo C, Ross EA, Kidawi N, Li T, Bell E, Chandel NS and Jordan VC: Intrinsic mechanism of estradiolinduced apoptosis in breast cancer cells resistant to estrogen deprivation. J Natl Cancer Inst 97: 1746-1759, 2005. PMID: 16333030. DOI: $10.1093 /$ jnci/dji400

35 Lewis-Wambi JS and Jordan VC: Estrogen regulation of apoptosis: How can one hormone stimulate and inhibit? Breast Cancer Res 11: 206, 2009. PMID: 19519952. DOI: 10.1186/ bcr2255

36 Figueira ACC, Figueira MC, Silva C, Padrao A, Oliviera PA, Ferreira RP and Duarte JA: Exercise training-induced modulation in microenvironment of rat mammary. Int J Sports Med 39: 885892, 2018. PMID: 30096722. DOI: 10.1055/a-0660-0198

37 Coelingh Bennink HJ, Verhoeven C, Dutman AE and Thijssen $\mathrm{J}$ : The use of high-dose estrogens for the treatment of breast cancer. Maturitas 95: 11-23, 2017. PMID: 27889048. DOI: 10.1016/j.maturitas.2016.10.010
Received December 4, 2019

Revised December 22, 2019

Accepted December 30, 2019 